Academic Platform Journal of Engineering and Science

\title{
Uyarlanabilir Çevrimiçi İngilizce Seviye Tespit Sınavı ile Türkiye’deki İngilizce Seviyesinin Analizi
}

\author{
${ }^{* 1}$ M. Fatih Adak, ${ }^{2}$ Mustafa Akpinar, ${ }^{3}$ Ali Uzunyolcu \\ ${ }^{1}$ Sakarya Üniversitesi, Bilgisayar ve Bilişim Bilimleri Fakültesi, Bilgisayar Mühendisliği Bölümü, Sakarya, Türkiye, \\ fatihadak@sakarya.edu.tr \\ ${ }^{2}$ Sakarya Üniversitesi, Bilgisayar ve Bilişim Bilimleri Fakültesi, Yazılım Mühendisliği Bölümü, Sakarya, Türkiye, \\ akpinar@sakarya.edu.tr, \\ ${ }^{3}$ Smart Eğitim, Kurucu Müdür, İstanbul, Türkiye, ali.uzunyolcu@ smarteducation.net
}

Araştırma Makalesi

Geliş Tarihi: 09.03.2020

Kabul Tarihi: 25.08.2020

\section{$\ddot{O} z$}

Globalleșen dünyamızda İngilizce artık dünya dili haline gelmiştir. Çoğu ülkede İngilizce; dili ana dil dışında, ikinci dil olarak öğretilmektedir. Gerek ülke politikaları olsun gerekse bireysel tercihler olsun İngilizce dilini öğrenmek için yüksek miktarlarda para harcanmaktadır. Bu alanda özellikle ülkemizde yapılacak çalışmalara, gerçekleştirilecek yatırımlara, karar verilecek politikalara 1şık tutmak amacıyla bu çalı̧̧mada, ülkemizdeki İngilizce seviyesinin analizi yapılmış ve faydalı bulgular elde edilmiştir. Bu analizin yapılması için proje kapsamında geliştirilen uyarlanabilir İngilizce çevrimiçi eğitim sistemi kullanılarak çok fazla sayıda gerçek kişiye çevrimiçi seviye tespit sınavı uygulanmışıı. Türkiye'deki her bir şehir ve bölge açısından faydalı bilgiler elde edilmiştir. Genel anlamda İngilizce seviyesinin düşük çıktığı ülkemizde beceri bazlı analiz yapılmış ve durumun bazı beceriler açısından daha da kötü olduğunu görülmüştür. Yaş ve cinsiyet bazlı analizler yapılmış olup çalışmada detaylı grafikleri verilmiştir. Çevrimiçi seviye tespit sınavlarında sınav süresi önemli bir etken olduğu için bu çalışmanın ana amaçlarından biri, çevrimiçi seviye tespit sınavlarında makul süresi belirleyebilmektir. Yapay zeka tekniklerini de kullanarak bu süre kabul edilebilir düzeye düşürülebilir. Belli yaş grupları ve özelliklere göre sistem geliştirecek girişimcilerin, bu çalışmadaki analizleri dikkate alıp geliştirmeyi ona göre yapmaları maksimum fayda almada önem arz etmektedir.

Anahtar Kelimeler: İngilizce seviye, uyarlanabilir eğitim, seviye tespit sınavı, Türkiye’deki durum

\section{Analysis of English Level in Turkey with Adaptive Online English Proficiency Exam}

\author{
${ }^{* 1}$ M. Fatih Adak, ${ }^{2}$ Mustafa Akpınar, ${ }^{3}$ Ali Uzunyolcu \\ ${ }^{1}$ Sakarya University, Faculty of Computer and Information Sciences, Computer Engineering Department, Sakarya, Turkey, \\ fatihadak@sakarya.edu.tr \\ ${ }^{2}$ Sakarya University, Faculty of Computer and Information Sciences, Software Engineering Department, Sakarya, Turkey, \\ akpinar@sakarya.edu.tr \\ ${ }^{3}$ Smart Eğitim, Founding Manager, Istanbul, Turkey, ali.uzunyolcu@smarteducation.net
}

\begin{abstract}
In our globalizing world, English has become the world language. English in most countries; is taught as a second language besides the native language. High amounts of money are spent on English language learning, whether it is country policies or individual preferences. In this study, in order to shed light on the studies to be carried out, investments to be made and policies to be decided in this field, the level of English in our country was analyzed and useful results were obtained. In order to perform this analysis, using the adaptive English online education system developed within the scope of the project used and a huge number of real person online exam information was obtained. Useful information was obtained for each of the cities and regions in Turkey. In general, skill level analysis was conducted in our country where the level of English was low and it was found that the situation was even worse in terms of some skills. Age and gender analyze were made and detailed graphics were given in the study. One of the main objectives of this study is to determine the reasonable time in online placement exams, since the exam duration is an important factor in online placement exams. This period can be reduced to an acceptable level by using artificial
\end{abstract}

*Sorumlu Yazar: Sakarya Üniversitesi, Bilgisayar ve Bilişim Bilimleri Fakültesi, Bilgisayar Mühendisliği Bölümü, Sakarya, Türkiye Sorumlu yazar adres, fatihadak@ sakarya.edu.tr 
intelligence techniques. It is important that the entrepreneurs who will develop the system according to certain age groups and characteristics take into consideration the analyzes in this study and develop them accordingly.

Keywords: English level, adaptive learning, placement test, the situation in Turkey
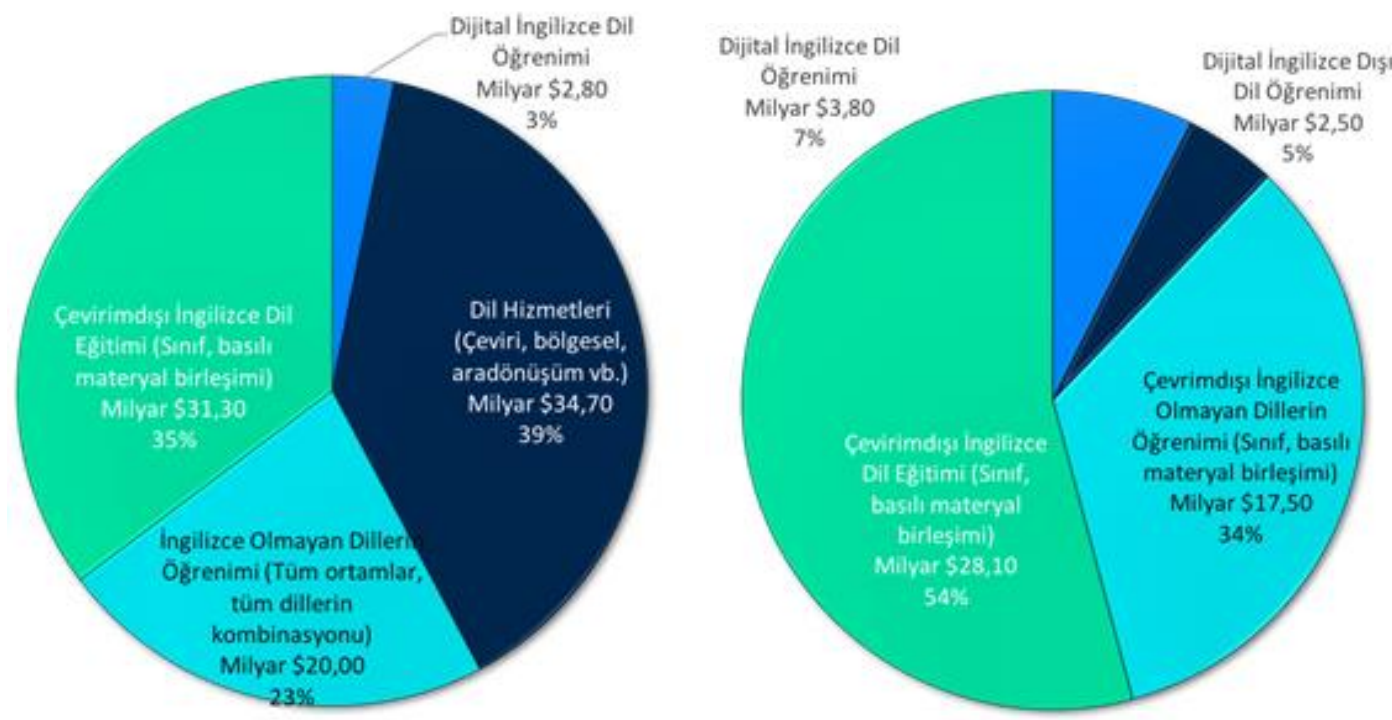

Şekil 1. İngilizce dilinin küresel dil öğrenim endüstrisindeki yeri (soldaki 2015 yılı, sağdaki 2020 yılı öngörüsü)

\section{GİRİS}

Gelişmekte olan birçok ülkede olduğu gibi ülkemizde de yabancı bir dili öğrenmek adına büyük zaman ve para harcanmaktadır. Fakat yoğun çalışma yaşamı ve eğitim hayatı; insanların dil öğrenimiyle ilgili zaman ayıramamasına sebep olmaktadır. Bu durumda da çevrimiçi sistemler önem kazanmaktadır. Yabancı diller arasında bilindiği üzere en büyük payı İngilizce almaktadır [1]. 2015 y1lında gerçekleşen ve 2020 yılı için öngörülen İngilizce dilinin küresel dil öğrenim endüstrisindeki yeri Şekil 1.'de gösterilmiştir [2]. Yine Şekil 1.'den görüldüğü üzere 2015 yılında dijital İngilizce dil öğrenimi \%3 iken 2020 yılında bu oranın \%7’e gelmesi öngörülmüştür.

Bunun yanında İngilizce dil öğreniminde dijital satın alma yoluyla en çok harcama yapan ülkeler arasında Türkiye bulunmaktadır. Buna rağmen İngilizce yeterlilik endeksinde Türkiye neredeyse listenin sonundadır [2]. Yabancı dil öğreniminde çevrimdışı (sınıf, basılı materyal birleşimi) ve çevrimiçi olarak iki farklı yaklaşım bulunmaktadır. Günümüzde yaygınlaşan öğretim materyallerinin dijital eöğrenme şeklinde olduğu ve hızlıca yaygınlaştığı görülmektedir. Dijitalleşmenin getirdiği fayda olarak erişimin kolay olması, süre kısıtlamasının olmaması, görsel ve işitsel yöntemlerle öğrenmeyi desteklemesi gösterilebilir. Sadece sınıfa ve bir yönteme bağlı kalmanın çok başarılı olmadığı sınıf dışında da bu sürecin etkili bir şekilde devam ettirilmesi gerektiği vurgulanmıştır [3]. Uyarlanabilir eğitim sistemlerinin amacı öğrenme sürecini hızlandırmak ve kişiye özgü eğitim modeli sunabilmektir [4]. Ayrıca, bu çevrimiçi sistemler öğretmenin sınıftaki öğrencileri daha iyi analiz edebileceği eğitim performanslarını öğrenciye özgü çıkartabilecek bir model sunmaktadırlar [5], [6]. Geriye doğru birçok bilginin kaydedilebildiği ve analiz için büyük bir verinin olduğu düşünülürse kişideki başarısızlığın temel sebebi kolayca analiz edilebilir. Kişiye özgü müdahalenin yapılabileceği bu sistemler her yaştaki bireyin eğitimi için önemlidir ve gelecekte vazgeçilmez bir duruma geleceklerdir.

\subsection{Benzer Çalışmalar}

Kişiye özgü eğitim modelleri literatürde incelendiğinde çok faydalı çalışmaların olduğu görülecektir. Kişileştirilmiş öğretim öğrenme stratejileri online eğitime yani bu çevrimiçi sistemlere entegre edilebilir [7]. Uyarlanabilirlikten kasit bireylerin öğrenme stillerinin çıkarılması ve buna göre yol izlenmesidir. Çünkü öğrenme stillerinin bireylerin başarılarını etkiledikleri görülmüştür. Nakayama ve arkadaşlarının yaptıkları bir çalışmada her birey bir öğrenme karakteristiğinin olduğundan bahseder ve bu karakteristiğinin çevrimiçi eğitimde dikkate alınması gerektiğini belirtir [8]. İngilizce öğrenmeye başlama yaşı, başladığı mekan ve cinsiyet gibi parametrelerin İngilizce seviyelerinde etkili olduğu görülmüştür [9]. Sadece belli becerilere yoğunlaşan çalışmalar da bulunmaktadır. Örneğin okuma becerisinde bulanık mantık temelli uyarlanabilir bir model geliştirilmiş ve başarılı geribildirimler alınmıştır [10]. Yine bulanık mantık kullanan bir diğer örnekte anlaşılmayan konuların işaretlenmesi için kişiye özgü bir yaklaşım tercih edilmiştir [11]. Kişilik yapısını ve öğrenme stillerini temel alan bir diğer çalışmada veri madenciliği alanında karar ağaçlarını kullanarak uyarlanabilir eğitim süreçlerini tanımlamışlardır [12]. Web tabanlı eğitimler için uyarlanabilir ve akıllı teknolojiler alanında birçok modelin referans aldığı eğitim alanında kuvvetli dayanakları olan Brusilovsky yine bu sistemlerin önemini vurgulamıştır [13], 
[14]. Uyarlanabilir çevrimiçi eğitimde özellikle popüler olmuş birkaç sistem incelenecek olursa, Anki, Supermemo, Orion ve Dualingo örnekleri verilebilir. Anki kelime ezberleme üzerine kurulmuş bir sistem olarak düşünülebilir, eskiden kartlar kullanılarak yapılan bu yöntemi çevrimiçi sisteme uyarlamışlardır [15]. Yine hatırlamaya yönelik uyarlanabilir bir sistemin geliştirildiği Supermemo belli bir beceriyi hedef aldığı ve başarılı olduğu söylenebilir [16]. Wiley tarafından geliştirilen Orion'da da uyarlanabilir bir sistemden söz etmek mümkündür. Detaylı raporlamanın olduğu bu sistemde başarılı sonuçlar alınmıştır [17].

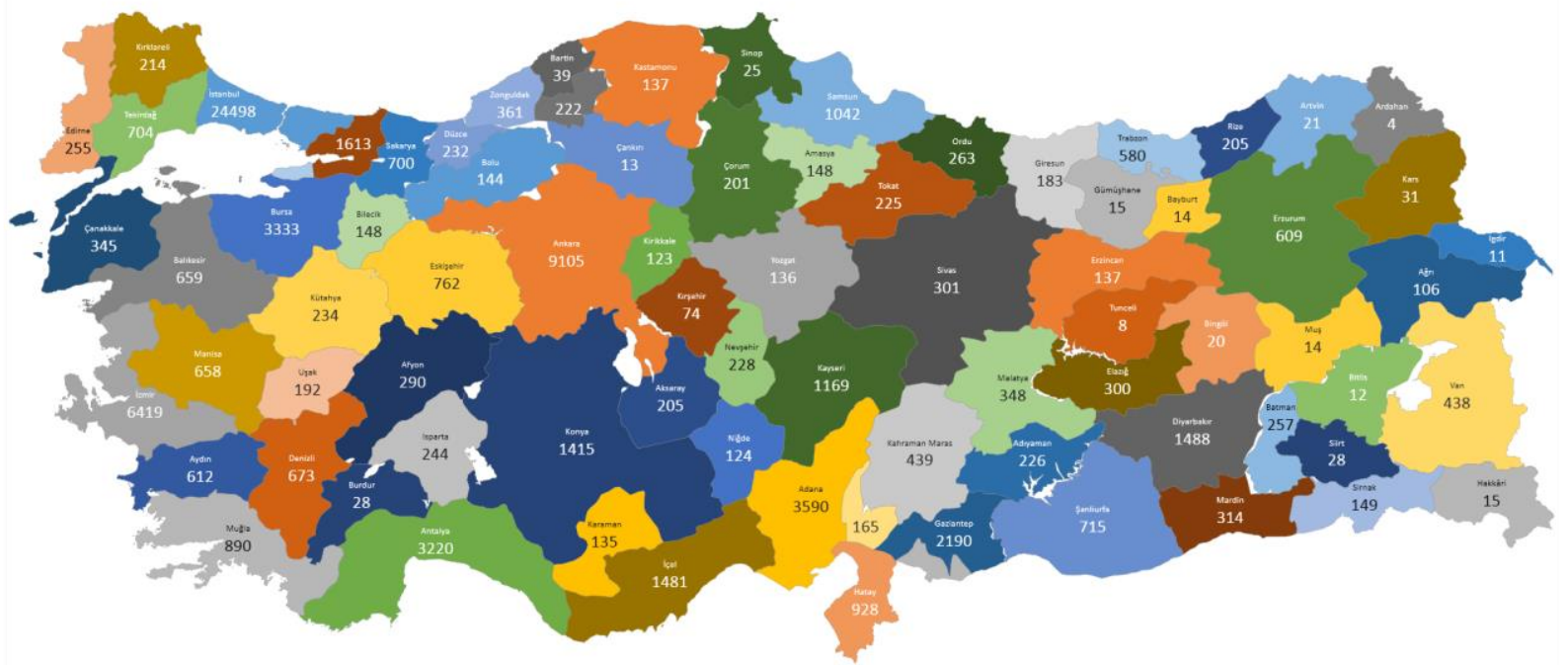

Şekil 2. İngilizce seviye tespit sınavına katılan kişilerin Türkiye il bazında dağılımı

İsmi yazılan bu dört sistemden belki de en etkilisi Dualingo'dur. Çevrimiçi dil eğitimini amaçlayan ve uyarlanabilir bir sistem olan Dualingo farklı becerileri içerisinde barındırır. Uzun süreli hafızayı başarılı kılmak için belli etmeden tekrar yolunu kullanır [18]. Bu çalışmanın temel amacı geliştirilen çevrimiçi İngilizce seviye tespit sınavından toplanan bilgiler ile analizler yapılmış ve çevrimiçi tespit sınavının süresi ortalama hangi aralıklarda olması gerektiği belirlenmeye çalışılmıştır. Yine yapılan analizlerle Türkiye içerisinde hangi bölgede hangi beceriye yönelik çalışmalar yapılması gerektiği, yaş aralıklarının ne olacağı beklenecek başarı değerlerinin hangi düzeylerde olması gerektiği belirlenmiştir. Bu çalışmada e-öğrenme sistemlerinin bir alt dalı olan çevrimiçi seviye belirleme sınavı İngilizce dili için gerçekleştirilmiş ve Türkiye için sonuçlar gösterilmiştir. Çalışmanın bundan sonraki aşamalarında metodoloji bilgisi verilecek ve bulgular gösterilecektir. Çalışmanın son kısmında ise sonuçlar ve tartışmalar belirtilecektir.

\section{Materyal ve Metot}

İngilizce seviye tespit sınavı kişinin İngilizce eğitimine en doğru yerden başlaması adına büyük önem taşımaktadır. Günümüzde İngilizce seviye belirleme sınavları Türkiye'de ÖSYM tarafından gerçekleştirilen YDS, eYDS ve YÖKDİL ile sağlanabilmektedir. YDS ve YÖKDİL sınavlarında gramer, kelime bilgisi ve okuduğunu anlama bölümleri bulunmaktadır. eYDS'de ise YDS'nin tamamen aynısı olup, sadece elektronik ortamda gerçekleştirilmektedir. Yurtdışı menşeili ILTS, TOEFL, IBT gibi İngilizce seviye tespit sınavlarında ise yazma, dinleme, okuma, dil bilgisi ve konuşma öne çıkmaktadır. Kişinin seviyesinin tespit edilmesinde çoğunlukla dilbilgisi, okuma, dinleme ve kelime bilgisi becerilerine dikkat edilmektedir. Fakat bu 4 beceride kişinin seviyesinin tespit edilebilmesi için çok fazla sayıda soru sorulabilmektedir. Bu işlemde sıkıcı olabileceğinden kişi sınavı erken bırakıp aslında daha yüksek seviyeden başlayabilecekken sistemde alt seviyelerden başlayabilmektedir. Bunun önüne geçebilmek için kişinin seviyesinin en hızlı bir şekilde belirlenmesi gerekmektedir. Bundan dolayı her beceri için ayrı biçimde çalışacak bir sistem uygulanmaktadır. Bu sistemde bir seviyeden 6 soru sorulmaktadır. Bu 6 soru içerisinde cevaplanan her sorudan sonra sorunun zorluk seviyesi artarak yeni bir soru gelmektedir. Eğer soru yanlış cevaplanırsa zorluğu daha düşük olan bir soru gelmektedir. Yani bir basamak modeli kullanılmaktadır. 6 soru içerisinde kullanıcı basamaklarda inip çıkabilmektedir. Bu şekilde 6 soru tamamlandığında kişinin bir üst seviyedeki 6 soruyu görüp göremeyeceğine karar verilmektedir ve böylece seviye belirlemesi yapılmaktadır. Bu çalışmada Smart eğitim çözümleri firması tarafından geliştirilmiş olan TÜBİTAK destekli Wext online yabancı dil eğitim platformu (https://www.wext.com/) içerisinde bulunan İngilizce seviye tespit sınavı yardımıyla 78.505 kişi çevrimiçi sınavına katılım göstermiştir. Bu; Türkiye ortalamasında ulaşılmış olan çok büyük bir katılımdır ve 01.01.2019 - 01.10.2019 tarihleri arasındaki verilerden oluşmaktadır. Toplanan bilgiler ışığında bu Türkiye'deki İngilizce seviye durumu birçok farklı perspektiften analiz edilmiştir. İngilizce seviye tespit sınavına katılan kişilerin Türkiye il dağılımı Şekil 2.'de verilmiştir.

En yüksek kullanıcı sayısı 24.498 ile İstanbul'da olurken, en düşük kullanıcı sayısı 4 ile Ardahan'da gerçekleşmiştir. 2018 TUİK (Türkiye İstatistik Kurumu) il bazında nüfus sayıları ele alındığında, il bazlı katılım oranı en yüksek Ankara'da 
(\%o1,654) gerçekleşirken sonrasında İstanbul ve Adana bu değere çok yakın katılıma sahip olmuştur. Nüfusa bağlı en düşük katılım oranı ise Muş ve Bitlis'te $(\% 00,343)$ gerçekleşmiştir. Türkiye'nin her köşesinden katılım olduğu için analiz ve istatistiksel veri olarak önemli sonuçlar vereceği açıktır. Yapılan çalışmada elde edilen veriler üzerinde bölgelere göre kullanıcı oranları, sınavı tamamlama yüzdeleri, sınavı tamamlama süreleri, cinsiyete ve yaşa göre dağılımlar ve son olarak seviyeye göre dağılımlar irdelenmiştir.

\section{Bulgular}

Yapılan analizler ve istatistiksel çalışmalar birçok faydalı sonucun alınmasını sağlamıştır. Bu bilgilerden biri sınavı tamamlama oranıdır. 78.505 kişi tarafından toplanan bilgiler doğrultusunda sınavı tamamlama oranları önemlidir. Çünkü özellikle okuma becerisinin ölçüldüğü bölüme gelindiğinde genelde kişiler sıkılıp sınavı kapatabilmektedirler. Türkiye geneli sınavı tamamlama oranları Şekil 3'te verilmiştir.

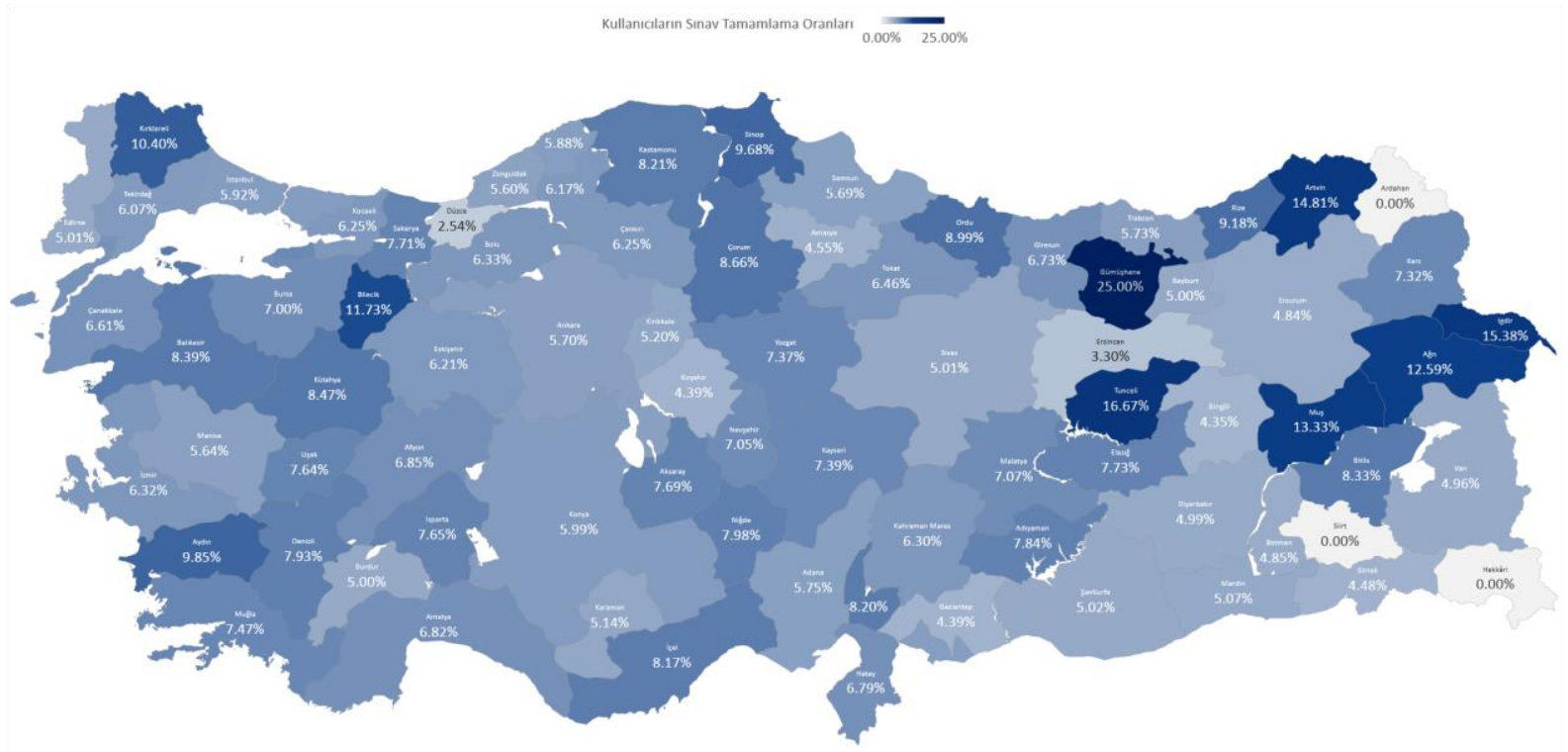

Şekil 3. Türkiye il bazında sınavı tamamlama oranları

Sınavı tamamlama oranı en yüksek Gümüşhane $\% 25$ oranla olurken, Siirt, Hakkâri ve Ardahan'da sinavlar tamamlanmamıştır.

Türkiye için illerden bağımsız ağırlıklı sınav tamamlama oranı \%9,98 olarak belirlenirken, iller bazında ağırlıksız sınav tamamlama oranı \%6,98 olarak belirlenmiştir.

Sınavı tamamlanması dışında sınavda harcanan süre de önemlidir. $\mathrm{Bu}$ bilgi aslında geliştirilen modelin kişinin seviyesini tespit etmek için ne kadarlık bir süresinin olduğunu göstermektedir. Model performanslarında bu süre referans olarak dikkate alınabilir. Kullanıcıların seviye tespit sınavında harcadıkları toplam süre ortalaması Şekil 4'te verilmiştir. Elde edilen verilere göre en yüksek ortalama süre 588,94 (9,81 dakika) saniye ile Erzincan'da olurken; en düşük süreyi bulmak için en az $\% 4$ sınav tamamlanan ve en az 5 örneklem bulunan iller ele alınmıştır. Buna göre Siirt, Hakkâri ve Ardahan'da sinavlar tamamlanmadiğından en düşük süre hesabında listede yer almamıştır. Bu üç il dışında
Düzce ve Erzincan'da da sınav tamamlama oranı \%4'ün altındadır (Şekil 3). Bingöl, Bitlis, Kilis, Sinop, Çankırı, Burdur, Kars, Tunceli, Artvin, Bayburt, Muş, Gümüşhane, Iğdır illerinde de 5 kişiden daha az sayıda sınavı tamamlayanlar olduğu için en düşük süre listesinde yer almamışlardır. $\mathrm{Bu}$ iki kısıtlama sonrasında en düşük ortalama süre 106,18 (1,81 dakika) saniye ile Kırıkkale'de gerçekleşmiştir (Şekil 4). Burada yer alan süreler üç farklı kullanıcı grubuna aittir ve bu gruplar sırasıyla; kendini denemek isteyenler, sistemi görmek isteyenler, kendini denemek isterken istemediği sonucu alacağını düşündüğü için sistemde soruları rastgele cevaplayanlar. Bu üç kullanıcı grubunda kendini denemek isteyenler dişında kalan kısımdaki kullanıcıların sistemde kalma süreleri incelenmiştir. $\mathrm{Bu}$ incelemeye göre gerçekten sınavı yapanların ortalama sürelerin 20 dakika civarında olduğu görülürken, diğer gruptaki kullanıcıların sistemde sınavı tamamladıkları süre 3 dakikanın altında olmuştur. Süre ile ilgili analizler "Yaşlara Göre Dağılımlar" kısmında detaylandırılmıştır. 


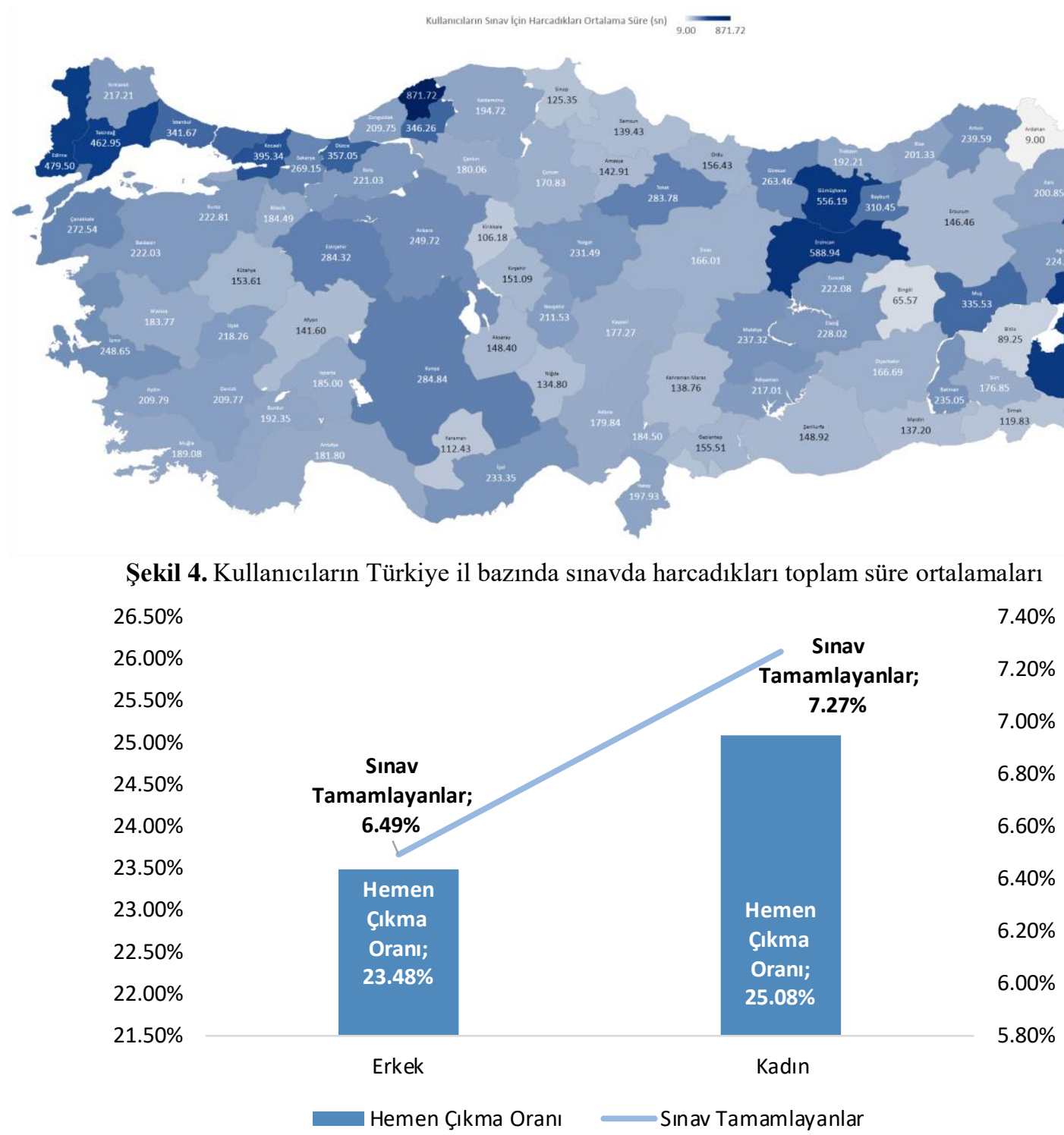

Şekil 5. Hemen çıkma ve sınavı tamamlama oranlarının cinsiyete göre dağılımı

\subsection{Cinsiyete Göre Dağılımlar}

$\mathrm{Bu}$ çalışmadaki analizlere göre kullanıcıların sınavı tamamlama oranları ve hemen çıkma oranları cinsiyete göre Şekil 5.'te verilmiştir. Sol eksen hemen çıkma oranını gösterirken, sağ eksen sınav tamamlama durumunun oranını göstermektedir. Hemen çıkma oranı kullanıcıların sisteme giriş yaptıktan sonraki ilk soruda sistemi terk etmelerini belirtmektedir. Buna göre kadınların hemen çıkma oranı erkeklere göre \%1,6 daha yüksek olmuştur. Sınav tamamlama durumunda ise kadınların erkeklerden \%0,78 daha yüksek olduğu görülmektedir. Türkiye genelinde ise cinsiyetten bağımsız olarak hemen çıkma oranı $\% 24,14$, sınav tamamlama oranı ise $\% 6,82$ olmuștur. $\mathrm{Bu}$ durum; kadınların erkeklere göre sınavı eğer yapmak isterlerse daha ciddiye aldıklarını, fakat erkeklerin kadınlara göre sınavı başta ciddiye alıp sonrasında tamamlamadıklarını göstermiştir.
Kullanıcı sayıları ve ortalama oturum süreleri açısından cinsiyete göre dağılımlar Şekil 6.'da verilmiştir. Sol eksen kullanıcıların sayılarını gösterirken, sağ eksen ortalama oturum sürelerini göstermektedir. Sınavı tamamlayan 78.505 kişinin 35.925'inin cinsiyeti belirlenebilmiştir. Buna göre, cinsiyet bildirerek sınava giren erkeklerin sayısı kadınlardan 5940 daha fazladır. Sinav ortalama oturum süresinde ise kadınlar erkeklere göre 36 saniye daha uzun sınavda kalmıştır. Sınav süresi yaklaşık ortalama 270 saniye $(4,5$ dakika) olmuştur. $\mathrm{Bu}$ sayılara sınavı tamamlamayan ve hemen çıkan kullanıcılar da dahil edilmiştir. Kullanıcıların zamana bağlı seviye tespit sınavına giriş oranları cinsiyet kırılımında Şekil 7'de verilmiştir. 10 aylık süre boyunca erkeklerin sayısı \%60 civarında olurken, kadınlar \%40 oranında seviye belirleme sınavına girmişlerdir. Çizgisel grafik ise kadın-erkek günlük bazda sınava giren kişi sayılarını göstermektedir. 


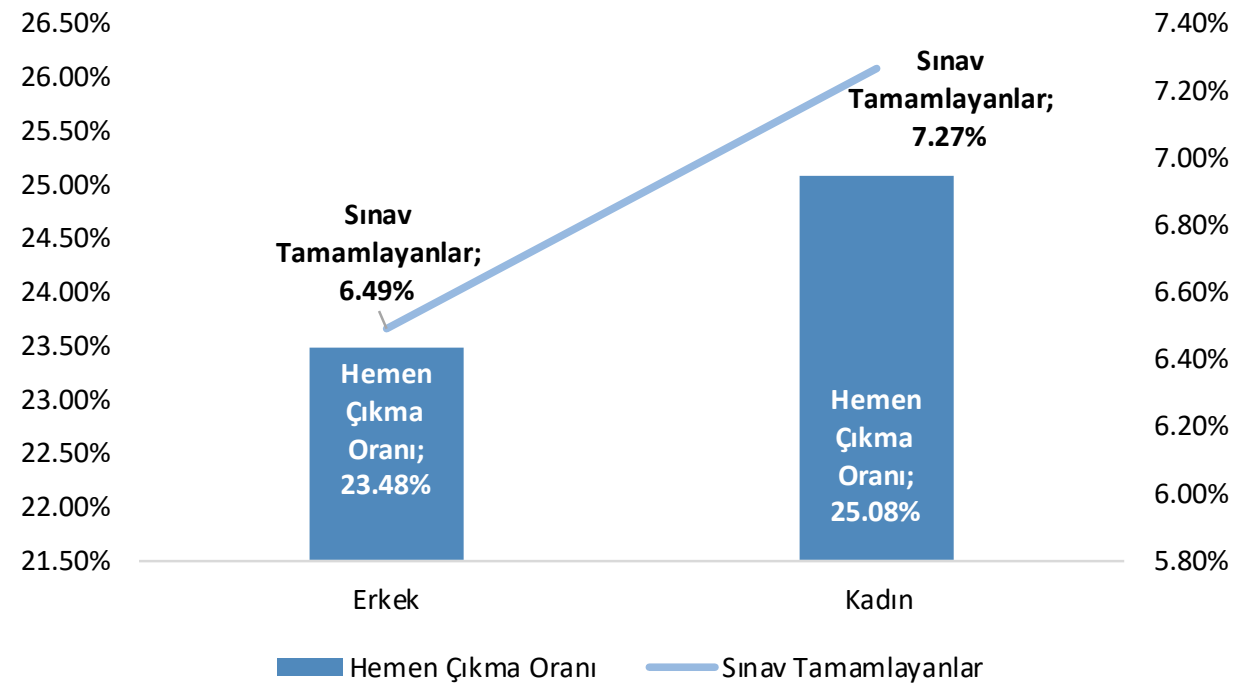

Şekil 6. Kullanıcı sayısının ve ortalama oturum süresinin cinsiyete göre dağılımı

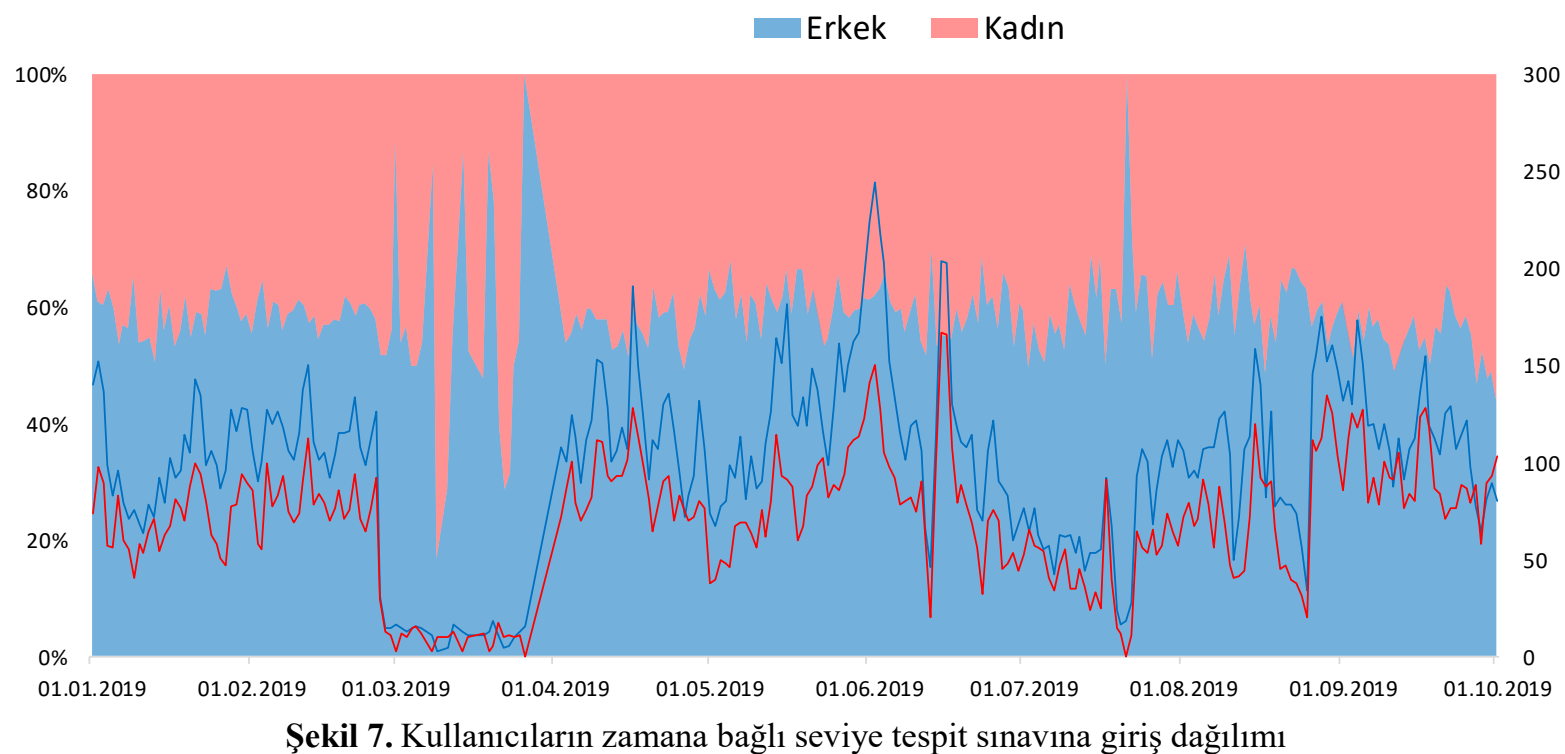

Grafiğin sol ekseni alan grafiğinin oranlarını gösterirken, sağ eksen kullanıcı sayılarını göstermektedir. Buna göre günlük sisteme giren kullanıcı dağılımlarında erkeklerin kadınlara göre daha yoğun sınava girdiği görülmüştür. Seviye tespit sınavının herkese duyurulması için Google, Facebook, Instagram reklamları kullanılmıştır. İki ay boyunca reklamlar ile sınava girişler sağlanırken, mart ayında reklamlar kapatılmış ve reklamın etkisi sınanmıştır. Bir ay boyunca reklamsız olarak sınava ortalama günde 20 kişi giriş yaparken, reklamların bulunduğu zamanlarda günde 184 kişi giriş yapmıştır.

\subsection{Yaş Gruplarına Göre Dağılımlar}

$\mathrm{Bu}$ çalışmada yapılan analizin diğer önemli bir perspektifi yaş dağılımıdır. Yaşam boyu öğrenmenin popüler olduğu günümüzde, yaş ile seviye belirleme sınavındaki davranışın arasındaki ilişki ortaya konulacaktır. Sınav tamamlama ve hemen çıkma oranları yaş gruplarına göre Şekil 8'de verilmiştir. Sol eksen hemen çıkma oranını gösterirken, sağ eksen sınav tamamlama durumunun oranını göstermektedir. Buna göre hemen çıkma oranı en düşük 25-34 yaş aralıklarında gerçekleşirken, en yüksek hemen çıkma oranı 65 yaş üstü kullanıcılarda gerçekleşmiştir. Sınav tamamlama durumunda ise 18-24 yaş aralığ $\%$ 10,05 ile en yüksek tamamlama oranına sahipken, 65 yaş üstü $\% 2,84$ ile en düşük sınav tamamlama oranına sahip olmuştur. Bu verilerde yaşı tespit edilemeyen kullanıcılar dahil edilmemiştir. Tüm yaş grubu tespit edilebilen kullanıcıların hemen çıkma oranı ortalamas1 \%23,77, sinav1 tamamlama ortalaması \%6,68 olmuştur. 45 yaş ve üstü kullanıcıların sınavda sıkıldıkları sınav tamamlama oranındaki düşüklükten, isteksizlikleri ise hemen çıkma oranındaki yükseklikten görülebilmektedir. Kullanıcıların yaşlarına göre sayıları ve ortalama oturum süreleri Şekil 9'da verilmiştir. Sol eksen kullanıcıların sayılarını gösterirken, sağ eksen ortalama oturum süreleri göstermektedir. Toplamda yaş grubu belirlenebilen 31.019 kişi bulunmaktadır. Buna göre sınava giren kullanıcılar 
arasında en yüksek sayıyı 25-34 yaş aralığı 10.769 kullanıcı ile almıştır. En düşük 65 yaş üstü kullanıcılar sınava girmiştir (1.111 kişi). Sınav ortalama oturum süresinde ise 35-44 yaş aralığındaki kullanıcıların 306,1 saniye ile en yüksek

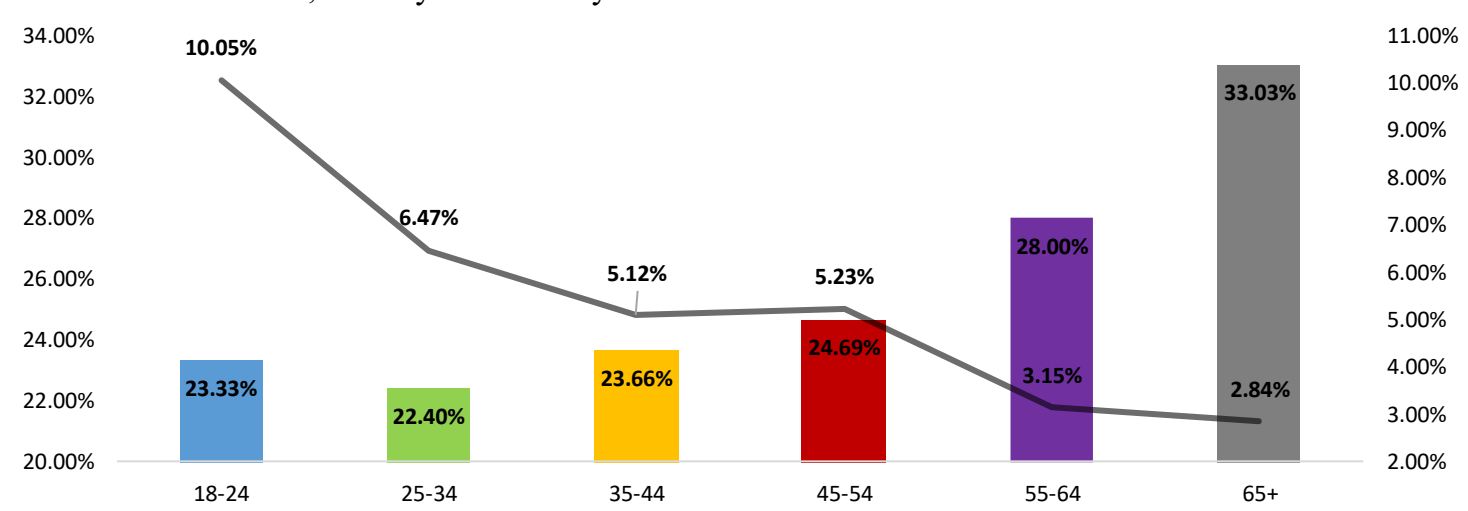

Şekil 8. Kullanıcıların yaşa göre alınmış sınav tamamlama ve hemen çıkma oranları

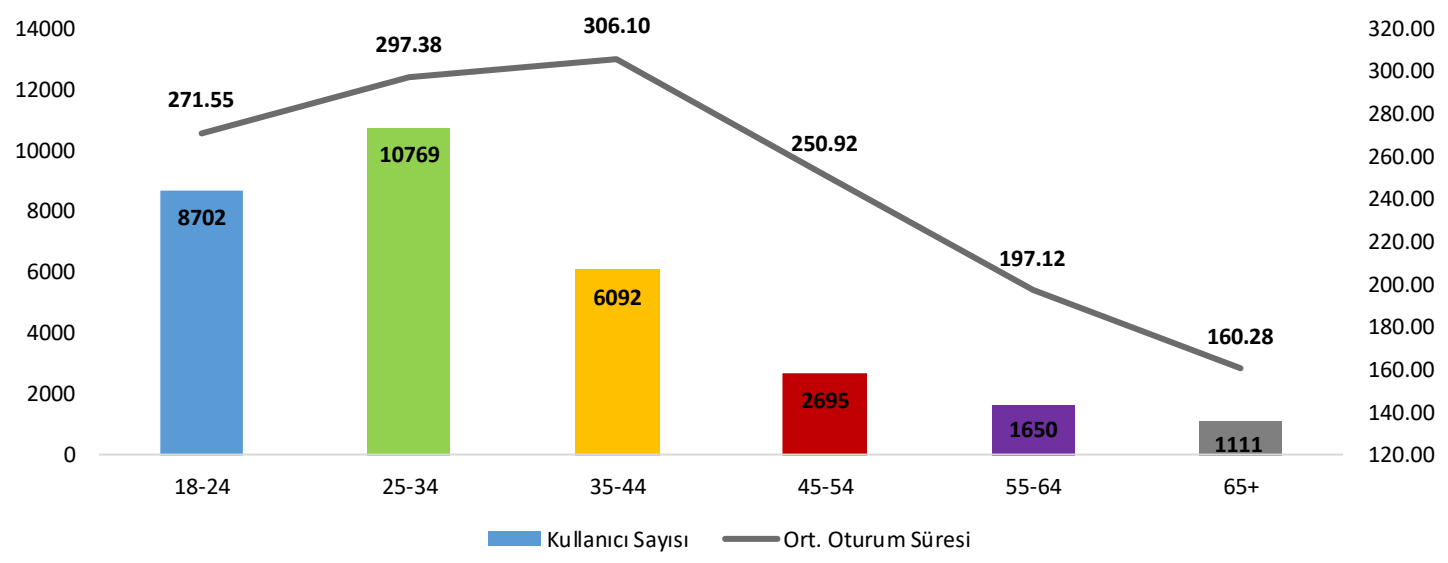

Şekil 9. Kullanıcıların yaşa göre sayıları ve ortalama oturum süreleri
Şekil 9., 18-44 yaş aralığının sınavı tamamlamada istekli ve düzgün biçimde gerçekleştirdiğini gösterirken, 45 yaş ve üstü kullanıcıların sıkılgan ve isteksiz olduklarını göstermiştir.

Kullanıcıların zamana bağlı seviye tespit sınavına giriş oranları yaş aralıkları temelli olarak alan grafiği tipinde Şekil 10 'da verilmiştir. Çizgi grafiğinde yaş aralık temelli günlük bazda sınava giren kişi sayıları gösterilmiştir. sistemde kalma süreleri olduğu bulunurken, 65 yaş üstü kullanıcıların 160,28 saniye ile en düşük sistemde kalma süreleri olduğu görülmüştür.

\section{$10.00 \%$ \\ $9.00 \%$ \\ $6.00 \%$ \\ $.00 \%$ \\ $00 \%$ \\ $.00 \%$}

\begin{tabular}{l}
$.00 \%$ \\
$.00 \%$ \\
$\%$ \\
$\%$ \\
$\%$ \\
$\%$ \\
\hline $00 \%$ \\
\hline 0
\end{tabular}

20.00

300.00

280.00

260.00

240.00

20.00

00.00

0.00

40.00

120.00

Grafiğin sol ekseni alan grafiğinin oranlarını gösterirken, să eksen kullanıcı sayılarını göstermektedir. 10 aylık süre boyunca 25-34 yaş aralığının en yüksek oranda kullanıcılar olduğu görülürken (\%34), 18-24 yaş aralığı kendisini takip etmiştir (\%28). 65 yaş üstü aralık en düşük kullanıcıya sahiptir (\%3). Yine mart ayında reklamların olmamasından dolayı sınavın gerçekleştirilme sayılarında düşüş meydana gelmiştir.

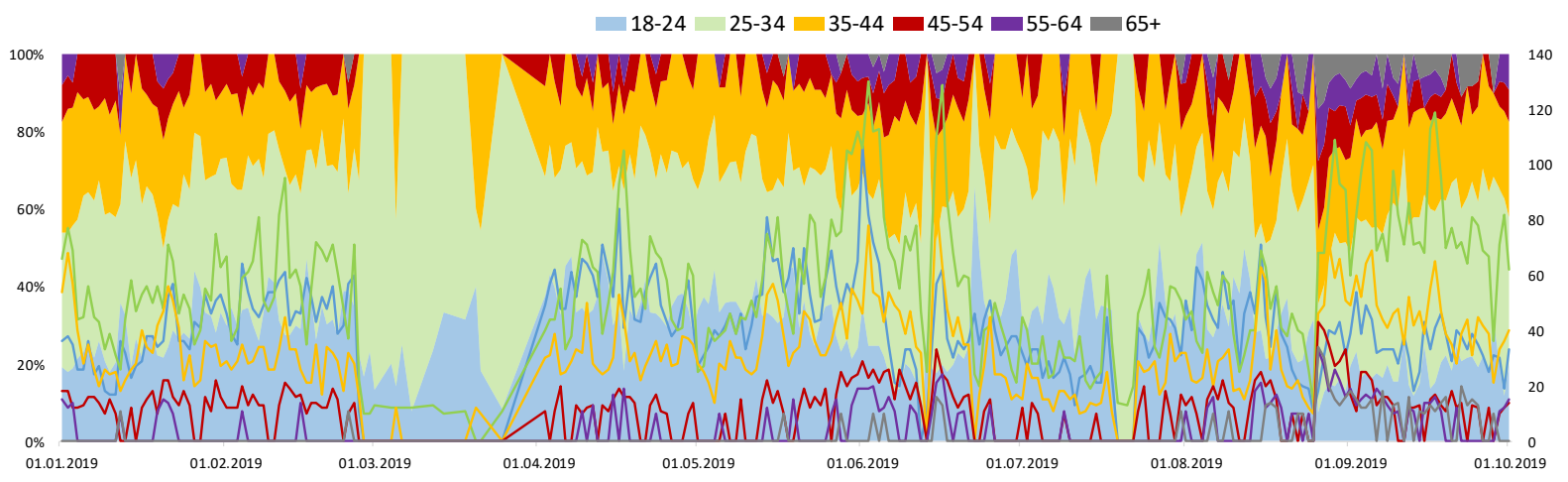

Şekil 10. Kullanıcıların yaşa göre sayıları ve zaman aralığı 


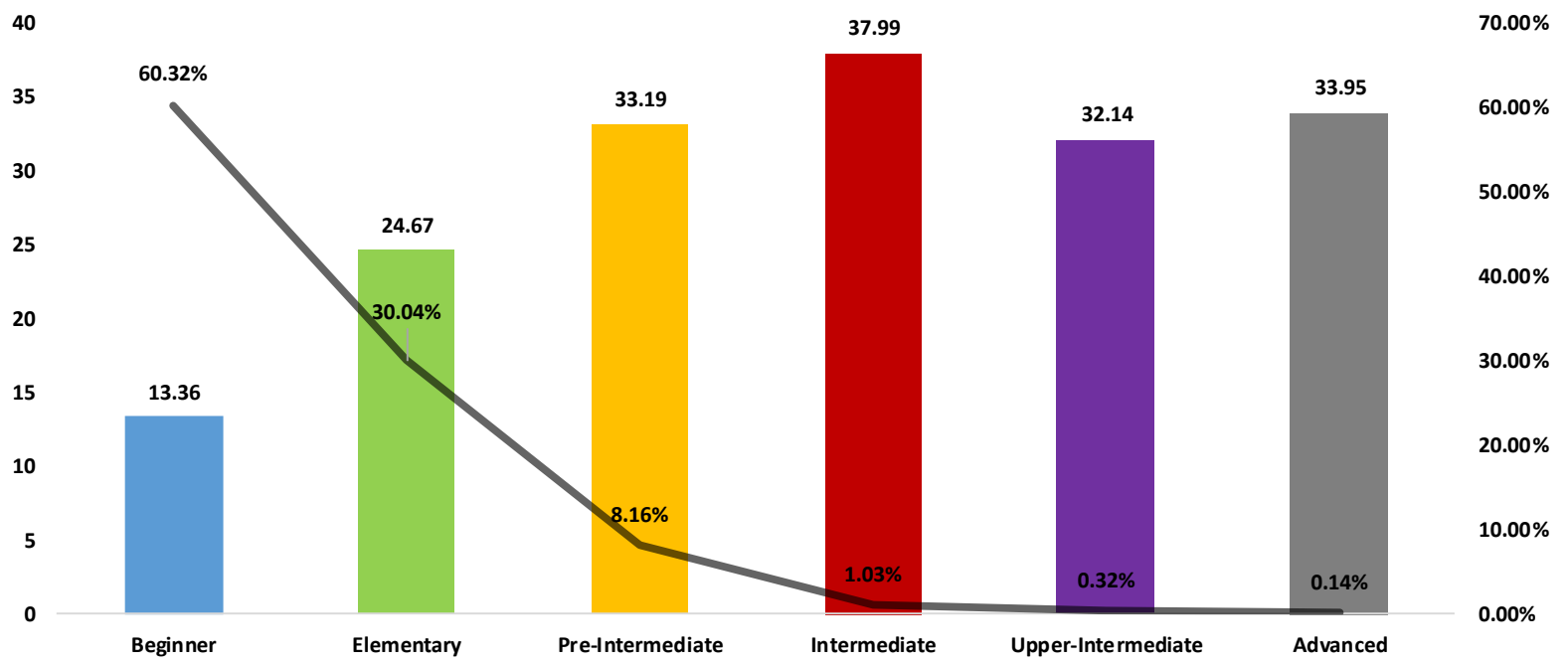

Şekil 11. Seviye tespit sınavına katılan bireylerin İngilizce seviyeleri

\subsection{Seviyelerine Göre Dağılımlar}

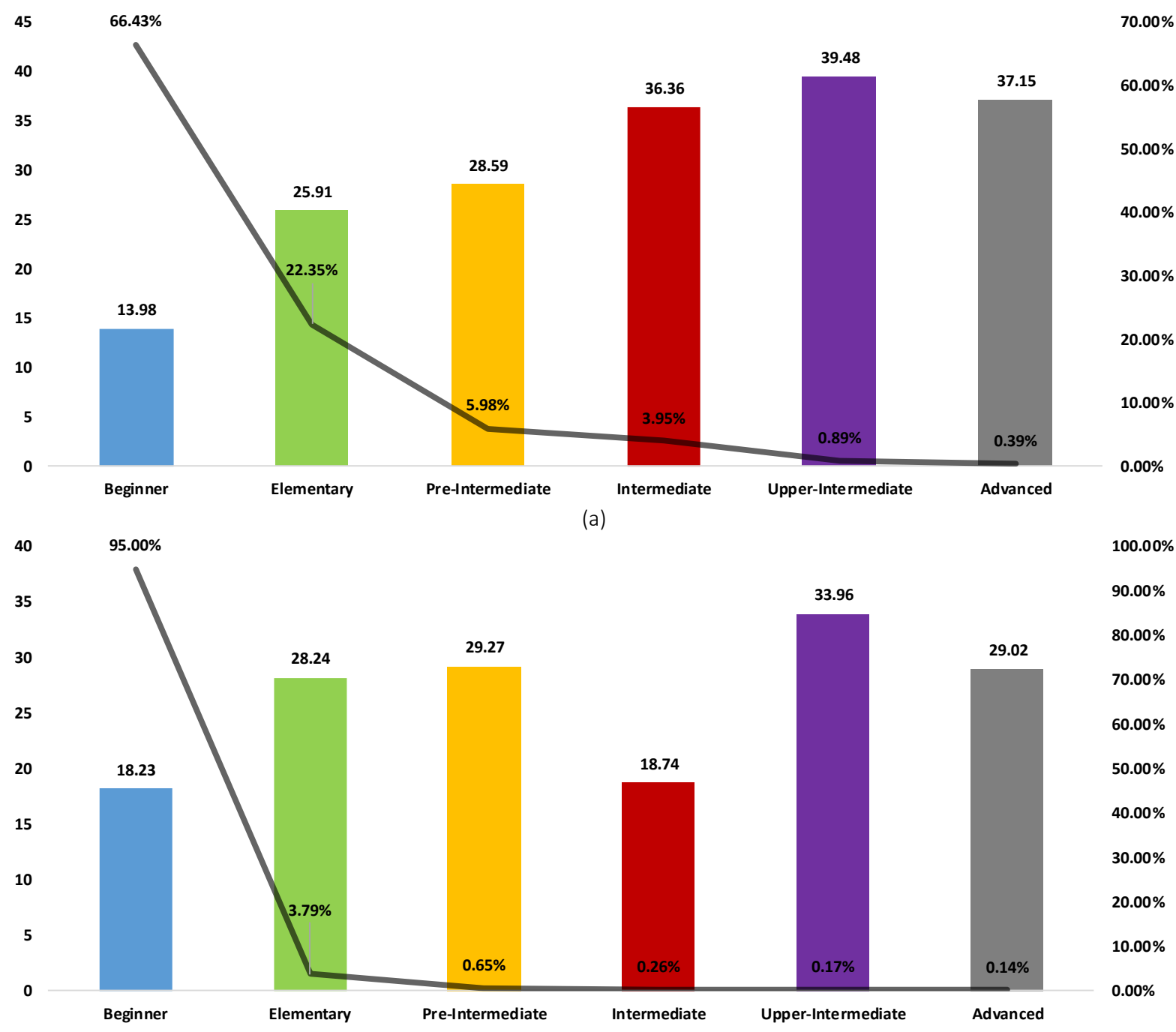

(b)

Şekil 12. Becerilere göre seviye dağılımları (a) Okuma , (b) dilbilgisi 
$\mathrm{Bu}$ Yapılan çevrimiçi seviye tespit sınavında, sınava katılan bireylerin genel İngilizce seviyeleri Şekil 11'de verilmiştir. Ayrıca aynı grafikte sınav sürelerinin ortalaması gösterilmiştir. Sol eksen ortalama sınav süresini gösterirken, sağ eksen ilgili seviyedeki kullanıcıların yüzdesini göstermektedir. Şekilde istatistikleri bulunan kişiler sınavı tamamlamış kişilerden oluşmaktadır. Elde edilen sonuçlara göre sınava katılan kullanıcıların \%60,32'si Başlangıç (Begineer) seviyesinde olup, bunu \%30 ile Temel (Elementary) seviye takip etmiştir. Kullanıcıların yaklaşık \%8,2'si Alt-Orta (Pre-Intermediate) seviyesinde bulunmuştur. Orta (Intermediate) ve üstü seviyedeki kullanıcıların toplamı \%2'nin altında kalmıştır. Sınavda geçirilen süre ele alındığında ise Orta (Intermediate) seviyedeki kullanıcıların ortalama 38 dakika ile en yüksek ortalama sürede sınavı tamamladıkları görülmektedir. Başlangıç (Begineer) seviyesindeki kullanıcılar ise sınavda ortalama 13,36 dakika harcamışlardır. Bunun sebebi sunulan modelde ilk 6 sorudan sonra başka soru görmemeleridir. $\mathrm{Bu}$ süre; başlangıç seviyesinin bir üstünde yer alan temel seviyenin neredeyse yarısı kadardır. Seviye belirleme sınavında dil bilgisi, kelime bilgisi, dinleme ve okuma becerilerinin sınandığı unutulmamalıdır. Dinleme ve okuma aşamalarının süre üzerinde etkisi fazladır. Şekil 11'de yer alan seviye tespit sinavı sonucunda İngilizce seviyeleri verilen kullanıcıların beceri bazlı seviyeleri Şekil 12 ve Şekil 13 'te verilmiştir. Şekil 12'de okuma ve dilbilgisi becerisine göre seviye dağılımları gösterilirken, Şekil 13'de kelime bilgisi ve dinleme becerilerine göre seviye dağılımları gösterilmiştir.

Şekil 12'de Sol eksen ortalama sınav süresini gösterirken, sağ eksen ilgili becerideki kullanıcıların yüzdesini göstermektedir. Sonuçlara göre sınava katılan kullanıcıların okuma becerisinde (Şekil.12(a)) \%66,43'ü, dilbilgisi becerisinde ise \%95' $\mathrm{i}$ Başlangıç (Begineer) seviyesinde sahip olup, bunu sirasiyla $\% 22,35$ ve $\% 3,79$ ile Temel (Elementary) düzey takip etmiştir. Orta (Intermediate) ve üstü seviyedeki okuma becerisine sahip kullanıcılar \%10'nun çok az üstündedir. Dilbilgisi becerisinde ise Orta Alt (Pre-Intermediate) ve üstü seviyedeki kullanıcılar \%1,22 oranında kalmıştır.

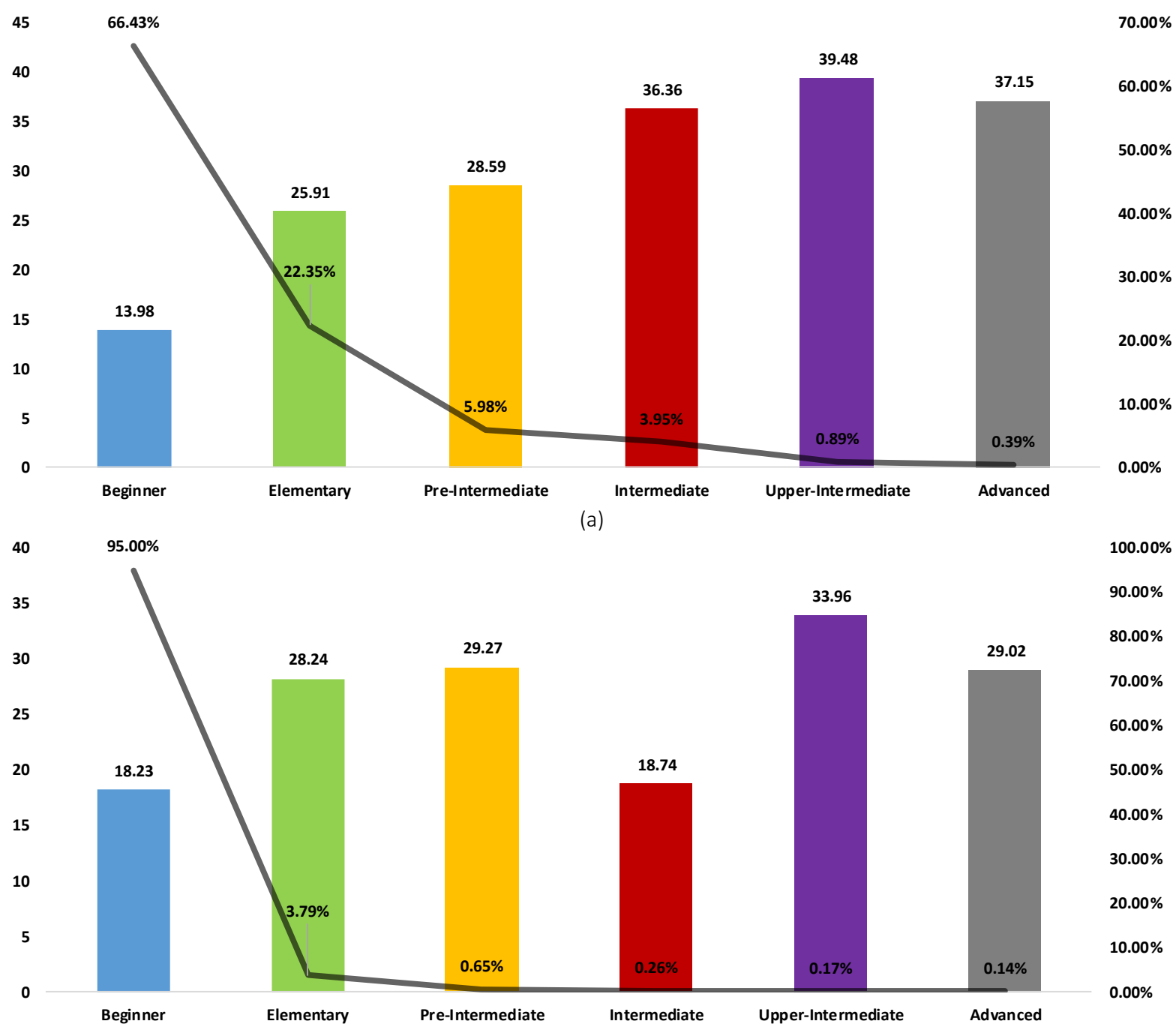

(b)

Şekil 13. Becerilere göre seviye dağılımları (a) Kelime bilgisi, (b)dinleme 
Sınavda geçirilen süre ele alındığında ise Orta Üst (UpperIntermediate) okuma seviyedeki kullanıciların ortalama 39,48 dakikada sınavı tamamladıkları görülmektedir. Bu süre dilbilgisi becerisinde Orta Alt (Pre-Intermediate) seviyesi için sınavda geçirilen süre 18,74 dakika olmuştur.

Sınav ortalama süresi için okuma becerisinde en yüksek Orta Üst (Upper-Intermediate) seviyesinde gerçekleşmiştir. Bu başarı grubu dilbilgisi seviyesinde de değişmemiştir ve en yüksek ortalama sınav süresine sahip olmuştur. Başlangıç (Begineer) seviyesindeki kullanıcılar ise okuma becerisinde sınavı ortalama 13,98 dakikada tamamlamışlar ve en düşük ortalama sınav süresine sahip olmuşlardır. Şekil 13'teki sonuçlara göre sınava katılan kullanıcıların kelime bilgisi becerisinde $\% 93,61$ ' $\mathrm{i}$, dinleme becerisinde ise $\% 61,65^{\prime} \mathrm{i}$ Başlangıç (Begineer) seviyesinde sahip olup, bunu sırasıyla $\% 3,95$ ve $\% 14,31$ ile Temel düzey takip etmiştir. Orta ve üstü seviyedeki dinleme becerisi kullanıcıların \%15'e yakını oluştururken, kelime bilgisi becerisinde bu oran \%1'in çok az üstündedir. Dinleme becerisinde yer alan sorularda sınırsız dinlenme hakkı verilmesinin ve sorudaki seçenek sayısının az olmasının buradaki kullanıcıların seviyesini yukarı çektiği öngörülmüştür.

Sınavda geçirilen süre ele alındığında kelime bilgisi ve dinleme becerileri birbirine yakın sonuçlar üretmiştir. Seviye arttıkça doğal olarak sınavda harcanan sürenin de artması beklenmektedir. Fakat kelime bilgisi becerisinde Orta (Intermediate) seviyesinde diğer tüm seviyeler göre daha fazla zaman harcandığı görülmüştür.

\section{TARTIŞMA VE SONUÇ}

$\mathrm{Bu}$ çalışmada iki ana unsur üzerinde durulmuştur. Birincisi beceri tabanlı ve kişisel özellikler ön planda tutularak seviye tespit sınavından alınan bilgiler ile analiz yapılmıştır. Diğer ana unsur çevrimiçi seviye tespit sınavının süresinin beceri bazlı hangi aralıklarda olacağının analizidir. Seviye tespit sınavlarında karşılaşılan problem birçok çalışmada seviye tespit sınavının basma kalıp bir şekille yapılıp kişinin seviyesinin doğru belirlenemediği için sistem içerisinde yanlış konumlardan başlayıp kişiyi sıkabilmesidir. Bu çalışmada geliştirilen uyarlanabilir seviye tespit sınavı yardımıyla kişisel özellikler dikkate alınarak en hızlı ve başarılı bir şekilde seviye tespiti yapılmış ve bireyler isabetli konumlardan başlatılmıştır. Yine literatürde incelenen seviye tespit sınavlarında uzun sürenin bireyleri sıktığını ve sınavı erken terk etme gibi sorunların olduğu analiz edilmiştir. Bunun için bu çalışmada geliştirilen sistem sayesinde bu süre en optimum noktaya indirgenmiş ve sistemden ayrılma oranını dikkate değer bir şekilde düşürmüştür. Ülkemizdeki İngilizce seviyesi diğer ülkeler ile karşılaştırıldığında oldukça geri olduğu bilinen bir durumdur. Bunun sebeplerini araştıran birçok çalışma yapılmıştır. $\mathrm{Bu}$ çalışmada uyarlanabilir İngilizce seviye tespit sınav sistemi kullanılarak yüksek sayıda kişi üzerinde seviye tespit sınavı uygulanmış ve analizleri çıkarılmıştır. Sınava girenlerin çok büyük bir kısmı başlangıç seviyesinde çıkarken bunun en büyük sebebinin dil bilgisi ve kelime bilgisi becerilerinin olduğu görülmüştür. Sınava girenlerin çoğunun genç yaş nüfusu olduğu ve ülkemiz açısından 2030 yaş grupları için ayrı plan-program yapılması gerektiği sonuçlardan elde edilmiştir. İngilizce seviye belirleme anlamında zeki bir model geliştirilecekse 15 dakika ya da maksimum 20 dakikada kişinin seviyesini belirlemelidir. Daha fazla süren çevrimiçi sınavlar kişiyi sıkmakta ve sınavı terk etmesine sebep olmaktadır. Sınav ilerleyişinde beceri bazlı yerine karma sistem tercih edilmesi sinavın terk edilmesinin önüne geçileceğini öngörmekte ve önerilmektedir. Böylelikle hem daha az soruda seviye belirlenebilirken hem de aynı tip soru sürekli arka arkaya gelmemiş olacaktır. Sınav başlamadan bazı kullanıcı özellikleri alınabilirse sınav ilerleyişi ona göre güncellenebilir. Örneğin; cinsiyete göre, sınava başlangıç beceri türü değiştirilebilir, eğitim düzeyine göre; sorularda kullanılacak resim ve materyal değiştirilebilir. Analizlerden bu gibi çıkarımlar elde edilmiştir. Günümüzde halen ciddi bir problem olan İngilizce eğitimi gelecekte de problem olmaya devam edecektir. $\mathrm{Bu}$ çalışmadaki ve bu çalışmadakine benzer analizler problemi çözmede bir basamak teşkil edebileceğinden önemli analizler olduğu düşünülmektedir.

\section{TEŞEKKÜR}

Bu çalışma TÜBİTAK 1501 kapsamında gerçekleştirilen, 3180703'nolu projeden elde edilen sonuçlardan oluşturulmuştur. Çalışmaya katkılarından dolayı Smart Eğitim Çözümleri Sanayi ve Tic. A.Ş. 'ye teşekkür ederiz.

\section{KAYNAKÇA}

[1] M. Saville-Troike and K. Barto, Introducing second language acquisition. Cambridge University Press, 2016.

[2] A. Insight, "The 2015-2020 Worldwide Digital English Language Learning Market," 2016.

[3] H. Aydoğan and A. A. Akbarov, "The Four Basic Language Skills, Whole Language \&amp; Intergrated Skill Approach in Mainstream University Classrooms in Turkey," Mediterr. J. Soc. Sci., May 2014, doi: 10.5901/mjss.2014.v5n9p672.

[4] A. Pardo, "Designing Learning Analytics Experiences," in Learning Analytics, New York, NY: Springer New York, 2014, pp. 15-38.

[5] M. Gusev and G. Armenski, "E-Assessment Systems and Online Learning with Adaptive Testing," 2014, pp. 229-249.

[6] H.-K. Wu, C.-Y. Kuo, T.-H. Jen, and Y.-S. Hsu, "What makes an item more difficult? Effects of modality and type of visual information in a computer-based assessment of scientific inquiry abilities," Comput. Educ., vol. 85, pp. 35-48, Jul. 2015, doi: 10.1016/j.compedu.2015.01.007.

[7] B. V. Koen, 'Creating a Sense of 'Presence' in a Web-Based PSI Course: The Search for Mark Hopkins' Log in a Digital World," IEEE Trans. Educ., vol. 48, no. 4, pp. 599-604, Nov. 2005, doi: 10.1109/TE.2005.850712.

[8] M. H. R. Nakayama, "The Impact of Learner Characteristics on Learning Performance in Hybrid Courses among Japanese Students.," Electron. J. e-Learning, vol. 5, no. 3, pp. 195-206, 2007. 
[9] F. Karahan, "Language attitudes of Turkish students towards the English language and its use in Turkish context," Cankaya Univ. J. Arts Sci., vol. 1, no. 7, pp. 7387, Aug. 2007.

[10] T.-C. Hsieh, T.-I. Wang, C.-Y. Su, and M.-C. Lee, "A Fuzzy Logic-based Personalized Learning System for Supporting Adaptive English Learning," J. Educ. Technol. Soc., vol. 15, no. 1, pp. 273-288, 2012.

[11] C. Troussas, K. Chrysafiadi, and M. Virvou, "An intelligent adaptive fuzzy-based inference system for computer-assisted language learning," Expert Syst. Appl., vol. 127, pp. 85-96, Aug. 2019, doi: 10.1016/j.eswa.2019.03.003.

[12] Y. Wang, M.-H. Tseng, and H.-C. Liao, "Data mining for adaptive learning sequence in English language instruction," Expert Syst. Appl., vol. 36, no. 4, pp. 7681-
7686, May 2009, doi: 10.1016/j.eswa.2008.09.008.

[13] P. Brusilovsky and E. Millán, "User Models for Adaptive Hypermedia and Adaptive Educational Systems," in The Adaptive Web, Berlin, Heidelberg: Springer Berlin Heidelberg, pp. 3-53.

[14] P. Brusilovsky, "From Adaptive Hypermedia to the Adaptive Web," 2003, pp. 21-24.

[15] "Anki." [Online]. Available: https://apps.ankiweb.net/.

[16] J. YANG and J. PARK, "Software Review: SuperMemo UX-Extreme English Advanced and Proficient," CALICO J., vol. 29, no. 4, pp. 718-726, 2012.

[17] B. McLaren, "Adaptive Online Learning The Present and Future of Education," Wiley, 2013.

[18] "Dualingo." [Online]. Available: https://tr.duolingo.com/. [Accessed: 27-Jan-2020]. 